\title{
Conceptual Framework of Risk Management for Public Building Procurement Systems in South- East, Nigeria
}

\author{
Ekwelem O. ${ }^{1}$, Okolie K.C. ${ }^{2}$ and Okongwu M.I. ${ }^{2}$ \\ ${ }^{1}$ Physical Planning Unit, University of Nigeria, Nsukka, Nigeria \\ ${ }^{2}$ Department of Building, Nnamdi Azikiwe University, Awka, Nigeria \\ DOI - http://doi.org/10.37502/IJSMR.2021.4506
}

\begin{abstract}
The study aimed at assessing the effectiveness of risk management process in public building procurement systems in South- East, Nigeria with a view to developing an effective risk management framework for public buildings in the study area. It was a desktop survey as the study was effected via literature review and a direct observation and walkthrough evaluation. The study was conducted in South-East Nigeria specifically: Anambra, Imo, Enugu, Abia and Ebonyi for a period of 6 months. There are two methodologies used in this paper. The first is reviewing secondary data in order to develop the conceptual framework. Then, a set of pilot questionnaire was distributed to 50 organizations with 40 returned answers to validate the conceptual framework. This paper presented an integrated conceptual framework to manage risks in public building procurement systems in South- East, Nigeria. The framework covered the process in risk management in public building procurement. A set of questionnaire was distributed to organizations to validate the conceptual framework. The findings showed that avoiding the risk is the best risk management technique that has the greatest impact on cost reduction in the construction companies. The study concluded that in order to improve the chance of success and reduce these potential risks associated with building construction projects in Nigeria, risk management that is guided with the above framework should be an important part of the decisionmaking process for a construction enterprise. Based on the findings, the study recommends risk management index for effective risk management process for public building procurement options in Nigeria.
\end{abstract}

Keyword: Risk Management, Conceptual Framework, Procurement, Procurement System, Nigeria, Public Building.

\section{Introduction}

Risk management is an important part of the decision-making process in construction and now widely accepted as a vital tool in the management of projects (Kangari 1995 cited in Wenzhe Tang et al., 2007). Risk management is a complicated process that interrelates with many other processes in the construction industry and on construction projects (Alexander, 1998; Chapman, 1997; Grey, 


\section{7 | International Journal of Scientific and Management Research 4(5) 106-123}

1995 cited by Holland, 2006). Investigating project risks includes studying potential events that may affect the scope, cost, time, or performance of the project's objectives. Investigating potential risks requires the collaboration of all disciplines contributing to the project. Technical, managerial, financial, and administrative departments of the participating firms need to cooperate to identify and respond to expected risk events. This integrative process needs practical experience to adapt the required environment (Smith, 1999 cited in Nnadi and Ugwu, 2014).

The Nigeria procurement process has largely remained same, though there are evidences of the use of many modern procurement methods (Ojo, Adeyemi, and Fagbenle, 2006). Procurement has also been adversely affected by kidnappings, vandalism, civil unrests and other such factors which have increased the risks associated with procurement. The Nigerian procurement industry went through a period of revival which resulted in the enactment of Procurement Act in 2007. Public procurement in Nigeria before the enactment of the Procurement Act was based on Treasury Circulars of 1958 which are now ineffective, outdated and encouraged poor procurement practices. Professionals in the Nigerian construction industry have overwhelmingly applauded the development and have described the Act as having the right strategy to help make procurement transparent, accountable and encourage good practice in procurement (Onyema, 2001). However, despite the triumph of enacting a Procurement Act, the Nigerian public procurement is still bedeviled by challenges due to the lack of widespread knowledge of the processes, blatant refusal to comply by some political interference and many other external and internal factors too numerous to mention (Onyema, 2001).

Procurement process is the entire procurement cycle starting from the identification of need, through to the completion of the contract. This process includes the 'Traditional' method which is also known as 'Design-Bid-Build method. This traditional method is most widely used in Nigeria. The other methods are put into one group called the 'Non-Conventional Methods' of procurement which include the Design and Build, Project Management, Construction management, Management Contracting, Labour-Only, Direct-Labour, and other discretionary procurements such as Alliancing, Partnering, and Joint Ventures (Babatude, Opawole and Ujaddighe, 2010).

The selection of an appropriate procurement method for a project is critical to both the client and other project participants as it is an important factor which contributes to the overall client's satisfaction and project success. Owing to the strategic nature of construction projects, the manner in which they are procured and the measures to ensure their success should not be underestimated. That means that all activities related to the process of procurement must be informed, structured and carried out in a manner designed to meet or enhance those objectives strategic to the needs of the client. Consequently, Richard (2005) recommends that any measure of project performance ought to be tied to the strategic outcome required by the construction client in terms of the investment/business case, the product, and the desired organizational and stakeholders' outcomes.

Risk in public building procurement systems is a variable in the process of construction whose occurrence results in uncertainty as to the final cost, duration and quality of the project. Some of 
the major causes of risk in public building procurement systems include design error, estimating error, competitive tendering risk, financial risk and changes in political and economic climate among others. While these risk factors are not unknown to the Nigerian construction practitioners, their assessment and management are yet to be investigated.

Risks have a significant impact on a construction project's performance in terms of cost, time, quality, health and safety. As the size and complexity of the projects have increased, an ability to manage risks throughout the construction process has become a central element in preventing unwanted consequences. How risks are shared between the project actors is to a large extent governed by the procurement system and the content of the related contract documents. Therefore, selecting an appropriate project procurement system is a key issue for project actors (Chan and Lee, 2008).

\section{Literature Review}

\section{Concept of Building Project}

A building is an enclosed structure that has walls, floors, a roof, and usually windows. A building or edifice is a structure with a roof and walls standing more or less permanently in one place, such as a house or factory (Max, 2002). Buildings come in a variety of sizes, shapes and functions, and have been adapted throughout history for a wide number of factors, from building materials available, to weather conditions, to land prices, ground conditions, specific uses and aesthetic reasons. Building is apartment or temporary structure enclosed within exterior walls and a roof, and including all attached apparatus, equipment, and fixtures that cannot be removed without cutting into ceiling, floors, or walls (Sturgis, 2011). Building is an activity in which a structure is constructed from materials, and which is distinct from manufacturing, trading, transportation, and other activities.

Buildings serve several the needs of the society - primarily as shelter from weather, security, living space, privacy, to store belongings, and to comfortably live and work. A building as a shelter represents a physical division of the human habitat (a place of comfort and safety) and the outside (a place that at times may be harsh and harmful).Ever since the first cave paintings, buildings have also become objects or canvasses of much artistic expression. In recent years, interest in sustainable planning and building practices has also become an intentional part of the design process of many new buildings (Paul and Alan, 2009).

Public building means any building or portion thereof, other than a privately owned residential structure, public housing structure, police, fire or correction structure, constructed wholly or partially with state or municipal funds, whether tax funds, funds obtained through bond issues or grants or loans under any state law, which is likely to be used by physically handicapped persons, including, but not limited to theaters, concert halls, auditoriums, museums, schools, libraries, recreation facilities, transportation terminals and stations, factories, office buildings and business establishments(Max, 2002).Public building means a building, whether for single or multitenant 
occupancy, and its grounds, approaches, and appurtenances, which is generally suitable for use as office or storage space or both by one or more federal agencies or mixed-ownership Government corporations (Bru, 2013). Public building may include: federal office buildings, post offices, custom houses, courthouses, appraisers stores, border inspection facilities, warehouses, record centers, relocation facilities, telecommuting centers, similar federal facilities, and any other buildings or construction projects the inclusion of which the President considers to be justified in the public interest (Moban, 2014).

\section{Concept of Procurement}

Project procurement has been described as an organized method or process and procedure for clients to obtain or acquire construction products (Ashworth and Hogg, 2007). The procurement of construction project is vast in scope because it involves the gathering and organizing of myriads of separate individuals, firms and companies to design manage and build construction products such as houses, office buildings, shopping complex, roads, bridges etc. for specific clients or "customers". Masterman (2002) describes project procurement as the organizational structure needed to design and build construction projects for a specific client. It is in a sense very true because the process of "obtaining" a building by a client involves a group of people, who are brought together and organized systematically in terms of their roles, duties, responsibilities and interrelationship between them. Apart from the traditional approach, there are now other "fasttracking" or innovative procurement systems used by the construction industry worldwide. The different procurement systems differ from each other in terms of allocation of responsibilities, activities sequencing, process and procedure and organizational approach in project delivery. These differences have invariably affected the project performance.

Ramus (2006) defines procurement, in a building context, as the overall process of acquiring a building. According to Rashid (2006), procurement derives from the word 'procure' which literally means 'to obtain by care or effort', 'to bring about' or 'to acquire'. Thus, project procurement is concerned with the organized methods or processes and procedures for obtaining or acquiring a construction product such as a house, shopping complex, road or jetty. It also involves arranging and coordinating people to achieve prescribed construction goals and objectives. Kadiri and Odusami (2003) define procurement methods as the various arrangements under which the activities required by a client to realize a building may be met. This implies that when a client wishes to extend or renovate an existing facility or construct a new one, there are a number of arrangements which can be used to acquire the services of the construction-related organizations or individuals to realize the desired product. The procurement of construction projects is vast in scope because it involves the organisation of myriads of separate individuals, firms or organizations to design, manage and construct facilities for specific clients and 'customers'. Today, there are several types of procurement arrangements in use in the construction industry. They range from the Traditional system to the several variations of 'fast-track' systems such as Design and Build, Management Contracting, Build-Operate-Transfer and so on. 


\section{Public Building Procurement Methods in Nigeria}

The Nigeria construction industry is modeled after the British system being our colonial master, although, since independence in 1960, it has incorporated the styles of other European countries, such as Italy, Germany and France (Mansfield, Ugwu and Doran, 2004). This industry is of paramount importance for employment and economic growth (Ogunsemi and Jagboro, 2006). The Nigerian construction industry forms nearly $70 \%$ of the nation's fixed capital formation (Federal Office of Statistics (FOS), 2004); yet its performance within the economy has been, and continues to be, very poor. For example, the Nigerian construction industry's contribution to employment has remained consistently at $1.0 \%$ over the last decade against the World Bank's average observation of about 3.2\% in developing countries (Idrus and Sodangi, 2008). The traditional Design-Bid-Build system of procurement is still dominant in the Nigerian construction sector and this may likely continue to be the trend (Idrus and Sodangi, 2008). In addition, the Nigerian construction sector comprises the clients, contractors, subcontractors, suppliers, and key professional actors responsible for design and supervision of projects. The professionals includes architects, engineers (structural and services), and quantity surveyors.

There are professional bodies that regulate the activities of these professionals. Delay in project execution is a major problem in the Nigerian construction industry. This occurs both in small and large projects. Virtually, all the projects executed over the years in Nigeria were faced with problem of delay in delivery (Odeyinka and Yusuf, 2007). Odeyinka and Yusuf (2007) observes that seven out of every ten projects suffer delay in Nigeria. Nigerian construction industry is faced with problem of cost overrun. Ogunsemi and Jagboro (2006) notes that one of the most serious problems the Nigerian construction industry is faced with is the project cost overrun, with attendant consequence of completing projects at sums higher than the initial sum. Therefore, working with realistic project estimate is necessary at the outset of a project work, which would eliminate uncertainty and as well provide a platform for project success. Idrus and Sodangi (2008) also observes that the last decade has however exposed the declining level of clients' satisfaction from the built facilities as a result of poor quality performance in addition to the perennial problems of time and cost overruns in the Nigerian construction industry.

The Nigerian construction industry continues to occupy an important position in the nation's economy, even though it contributes less than the manufacturing or other service industries (Aibinu and Jagboro, 2002). This industry plays an important role in the economy, and the products of its activities are so vital to the achievement of national socio-economic development goals of creating job opportunities and social amenities and infrastructures (Anaman and OseiAmponsahAn, 2007). Maizon (2006) recognises that one of the principal reasons for the poor performance of the construction industry is the use of inappropriate procurement systems for the execution of construction projects. Several factors amongst which are increasing complexity of buildings, the need for greater financial management and the need to reduce design and construction periods have put pressure on the client to seek alternative approaches to the Traditional method of procurement. Muriro and Wood (2010) argues that the proliferation of the 


\section{1 | International Journal of Scientific and Management Research 4(5) 106-123}

procurement methods used for construction necessitated a comparison of the performance associated with each of them.

However, the focus of most previous studies on procurement methods has been on performance with very few studies on selection criteria. For instance, Babatundeet.al.. (2010) appraises the procurement methods in use in Nigeria and concluded that the Traditional Contract Procurement method was the one most commonly used in the country.

Ojo (2009) investigated the performance of procurement types in Nigeria using the concept of performance indices. The study which compared the Traditional Contract, Management Contracting, Design and Build and Build-Own-Operate-Transfer methods concluded that the Traditional procurement was the most commonly used in Nigeria. Furthermore, Ojo and Aina (2010) investigates the performance of a variant of the Traditional method (Lump sum contract method), Management Contracting method, Design and Build method and Build-Own- OperateTransfer method against selection criteria in Nigeria. The study concludes that in the Nigerian construction industry, participants did not agree on the performance of procurement methods and selection criteria. Similarly, Kadiri and odusami (2003) compares the cost and time performance of Direct Labour and Labour-only Contract procurement methods in Nigeria. The study which used archival data of projects executed using the two systems concluded that the labour-only method was more effective in terms of both cost and time performance. Ogunsanmi et al (2003) investigates the factors influencing the performance of Traditional and the Labour-only procurement methods in Nigeria. The study concludes that the Traditional method was more in use than Labour-only method.

In the views of Ibiyemi et al (2008) the Traditional Procurement method is not a suitable method for fast tracking projects because of its sequential nature that projects are designed before being constructed. This is a major disadvantage for this method of procurement as it does not support fast tracking. However, Babatunde et al (2010) indicates that separation of design, tendering process and construction phases in Traditional Procurement method should be viewed as separate tasks in which the design must be completed before construction phase starts. This study hence, draws on this sequential feature to classify Traditional procurement method as Design-Bid-Build system. This is another nomenclature for the Traditional Procurement method. Dada (2012) also indicates that Traditional Procurement method has been reported for use in project delivery in many countries of the World in which Nigeria is one. Precisely, this study confirms that Traditional Procurement method has long being used by both public and private sectors of the Nigerian economy. This study compares perceptions of stakeholders on some issues of Traditional procurement method germane to them and the Nigerian economy. The study finds out that all the issues compared on Traditional Procurement method are the same for all stakeholders.

Recent research efforts in documenting the use of the method in Nigeria are evidenced from research works of Ogunsanmi, Iyagba and Omirin, (2003); Samatania Consult Limited, (2012); Babatunde, Opawole and Ujaddughe, (2010) and Dada (2012). In Nigerian construction industry 


\section{2 | International Journal of Scientific and Management Research 4(5) 106-123}

Labour-only procurement has recently been accepted by stakeholders for use in their various construction projects. According to Ogunsanmi et al (2003) this method has found more patronage not only in Nigeria but also in some other sub-Saharan countries of Uganda, Zimbabwe, Botswana, Kenyaand South Africa. Many private individual projects of different constructions types ranging from residential, religious, social and other specialized buildings had been procured through the use of Labour-only method.

In addition, Ogunsanmi et al (2003) in comparing the performance of Traditional and Labour-only procurements in some housing construction projects comes to the conclusion that Traditional procurement is better in overall performance whereas Labour-only takes shorter time to achieve the design preparation processes as well as the building time. In the views of Department of Building and Housing (2012), Labour-only is used by clients for better control of their building process as well as strategy for saving money on projects. This situation of using Labour-only in projects also agrees with the postulates of Ogunsanmi et al (2003). Similarly, other contemporary study on Labour-only such as Hardie (2007) has indicated that the use of the method by clients involves commitment of time, energy and diplomacy by the client to achieve the project. This study also confirms that most people engage Labour-only Builder to save money on their projects. Equally, Samatania Consult Limited (2012) identifies the use of Labour-only with minor alteration/modification works involving repairs, maintenance and refurbishments. It further indicates that the downturn of the Nigerian economy of the 1980 through 1990 has forced building employers/promoters to expand the scope of use of Labour-only for construction of new projects. It is in support of this advocacy that the study of Babatunde, Opawole and Ujaddughe (2010) mentions that concept of Labour-only has since been applied to construction of large projects in Nigeria.

\section{Public Procurement Practice in Nigeria}

According to Turner (1990), procurement is an activity in commerce and industry that means purchasing the tendering and selection required to obtain anything from paper clips to power stations. Obiegbu, (2005) stressed the crucial role of selecting the right procurement system to attain projects success. He defines it as the process that creates, manages and fulfils contracts. According to the Bureau of Public Procurement (2008) Public procurement is the process by which governments buy inputs for vital public sector investments. Those investments, both in physical infrastructure and in strengthened institutional and human capacities, lay foundations for national development.

In an attempt to relate public procurement to its users, Sani (2002) refers to procurement organizations as those that have the need in acquiring buildings of any type for certain purposes. Such organizations include the federal, state and local governments, parastatals of the three tiers of government, tertiary educational institutions, corporations etc. The need and level of procurement also varies and depends on the financial capability of the procuring organization. In the current procurement procedure in Nigeria, purchase orders are not processed in a timely fashion 


\section{3 | International Journal of Scientific and Management Research 4(5) 106-123}

and delivery dates are not being met (Bureau of Public Procurement, 2008; Adebiyi, et al, 2010). According to Attah (2009), procurement accounts for about 80 per cent of Nigerian government expenditures at all levels. Procurement of goods, works and services are thus central to daily government activities and as such forms the center point of the Nation's economic rating. Meeting the infrastructure demands of the nation will depend largely on the efficiency of the nation's procurement system.

In the Nigerian building industry, the conventional process of procurement is one in which the client appoints professional advisers or consultants to act on his behalf principally to obtain his brief, carry out preliminary estimates, design, prepare bills of quantities and other tender documents, recommend a competent contractor and supervise the construction phase (Izam, 2007). The Federal Government established the National Council on Public Procurement and the Bureau of Public Procurement (BPP) to monitor prices of tendered items and keep a database of standard prices. The bureau is mandated to publish details of major contracts to prevent fraudulent and unfair procurement The B.P.P is charged with overseeing of public procurements by monitoring the various ministries, agencies and other government bodies subject to the public procurement regime (Anonymous, 2011). It therefore oversees the procuring entities and indirectly oversees all qualifying public procurement in the country.

Specifically, the BPP's functions include formulating the general policies and guidelines for procurement as well as reviewing the procurement and award of contract procedures of every procurement entity. It also certifies procurements prior to the award of contracts and performs procurement audits (it is mandated to submit reports from such audits to the National Assembly biannually). The BPP has powers to call for such information, documents, records and reports in respect of any aspect of any procurement proceeding as it deems fit.

The Public Procurement Act (2007) establishes the National council on Public Procurement and the Bureau of Public procurement as the regulatory authorities responsible for the monitoring and oversight of public procurement, harmonizing the existing Government policies and practices by regulating, setting standards and developing the legal framework and professional capacity for public procurement in Nigeria. It can therefore be said to be a standard guide for efficient, effective, transparent and successful tendering for public projects in Nigeria.

\section{Concept of Risk Management}

Risk management is an activity which integrates recognition of risk, risk assessment, developing strategies to manage it, and mitigation of risk using managerial resources (Lerad, 2014). Some traditional risk managements are focused on risks stemming from physical or legal causes (e.g. natural disasters or fires, accidents, death). Risk management is a management discipline whose goal is to protect the asset, reputation, and profits an organization by reducing the possible losses or damages before they occur (Bing, Tiong, Fan and Chew, 2009). Risk management is one of the nine knowledge areas (i.e., integration management, scope management, time management, cost 
management, quality management, human resource management, communications management, risk management, and procurement management) propagated by the Project Management Institute (PMI, 2008). Zou et al (2007) describes risk management in the construction project management context as a systematic way of identifying, analysing and dealing with risk as associated with a project with an aim to achieve the project objectives Williams (2005) futher describes project risk management as an integrated process which includes activities to identify project uncertainty, estimate their impact, analyse their interactions, control them in the execution stage, and even provide feedback to the maintenance of collective knowledge asset.

Risk management is central part of any organizations' strategic management. It is the process whereby organizations methodically address the risks attaching to their activities with the goal of achieving sustained benefit within each activity and across the portfolio of all activities. The focus of good risk management is the assessment and estimation of these risks. Its objective is to add maximum sustainable value to all the activities of the organization. It must translate the strategy into tactical and operational objectives, assigning responsibility throughout the organization with each manager and employee responsible for the management of risk as part of their job description. It supports accountability, performance, measurement and reward thus. Preparing operational efficiency at all level. Risk management is a straight forward process in it requires the evaluation of risk and the execution of risk management strategy (Ashworth et al, 2007).

\section{Methodology}

There are two methodologies used in this paper. The first is reviewing secondary data in order to develop the conceptual framework. Then, a set of pilot questionnaire was distributed to 50 organizations with 40 returned answers to validate the conceptual framework.

\section{Conceptual Framework of Risk Management for Public Building Procurement}

\section{Systems}

Table 1: Summary of Procurement options and risk management practices in the buildings investigated

\begin{tabular}{|l|l|l|l|l|}
\hline S/N & Name/Location & $\begin{array}{l}\text { Type of the } \\
\text { project }\end{array}$ & $\begin{array}{l}\text { Procurement } \\
\text { Option }\end{array}$ & $\begin{array}{l}\text { Risk } \\
\text { Practice }\end{array}$ \\
\hline $\mathbf{1}$ & $\begin{array}{l}\text { New Workers Secretariat } \\
\text { Building in Umuahia, Abia } \\
\text { State }\end{array}$ & $\begin{array}{l}\text { Civil } \\
\text { Engineering }\end{array}$ & Design-build & $\begin{array}{l}\text { Risk Identification } \\
\text { Risk Quantification } \\
\text { Risk } \\
\text { Development } \\
\text { Risk Response Control }\end{array}$ \\
\hline $\mathbf{2}$ & $\begin{array}{l}\text { Anambra State Government } \\
\text { Secretariate Building, } \\
\text { Awka Building }\end{array}$ & $\begin{array}{l}\text { Design-bid } \\
\text { and build } \\
\text { (DBB) }\end{array}$ & $\begin{array}{l}\text { Risk Identification } \\
\text { Risk Quantification } \\
\text { Risk } \\
\text { Development Response }\end{array}$ \\
\hline
\end{tabular}




\begin{tabular}{|c|c|c|c|c|}
\hline & & & & Risk Response Control \\
\hline 3 & $\begin{array}{l}\text { Ebonyi State Government } \\
\text { Secretariat, Abakaliki }\end{array}$ & $\begin{array}{l}\text { Civil } \\
\text { Engineering }\end{array}$ & Design-build & $\begin{array}{l}\text { Risk Identification } \\
\text { Risk Quantification } \\
\text { Risk Response } \\
\text { Development } \\
\text { Risk Response Control }\end{array}$ \\
\hline 4 & $\begin{array}{l}\text { Enugu State Government } \\
\text { Secretariat, Enugu }\end{array}$ & $\begin{array}{l}\text { Civil } \\
\text { Engineering }\end{array}$ & Design-build & $\begin{array}{l}\text { Risk Identification } \\
\text { Risk Quantification } \\
\text { Risk Response } \\
\text { Development } \\
\text { Risk Response Control }\end{array}$ \\
\hline 5. & $\begin{array}{l}\text { Imo State Government } \\
\text { Secretariat }\end{array}$ & Builc & $\begin{array}{l}\text { Design-bid } \\
\text { and build } \\
\text { (DBB) }\end{array}$ & $\begin{array}{l}\text { Risk Identification } \\
\text { Risk Quantification } \\
\text { Risk Response } \\
\text { Development } \\
\text { Risk Response Control }\end{array}$ \\
\hline 6. & $\begin{array}{l}\text { Administrative Buildings in } \\
\text { Abia State University, } \\
\text { Uturu }\end{array}$ & Building & $\begin{array}{l}\text { Design-bid } \\
\text { and build } \\
\text { (DBB) }\end{array}$ & $\begin{array}{l}\text { Risk Identification } \\
\text { Risk Quantification } \\
\text { Risk Response } \\
\text { Development } \\
\text { Risk Response Control }\end{array}$ \\
\hline 7. & $\begin{array}{l}\text { Administrative Building in } \\
\text { Nnamdi } \\
\text { University, Awka }\end{array}$ & Building & $\begin{array}{l}\text { Design-bid } \\
\text { and build } \\
\text { (DBB) }\end{array}$ & $\begin{array}{l}\text { Risk Identification } \\
\text { Risk Quantification } \\
\text { Risk Response } \\
\text { Development } \\
\text { Risk Response Control }\end{array}$ \\
\hline 8. & $\begin{array}{l}\text { Prof Festus Aghagbo } \\
\text { Nwankwo Digital Library, } \\
\text { Awka }\end{array}$ & Building & $\begin{array}{l}\text { Design-bid } \\
\text { and build } \\
\text { (DBB) }\end{array}$ & $\begin{array}{l}\text { Risk Identification } \\
\text { Risk Quantification } \\
\text { Risk Response } \\
\text { Development } \\
\text { Risk Response Control }\end{array}$ \\
\hline 9. & \begin{tabular}{lcr} 
Agriculture & \& & Natural \\
Resources & Management \\
Faculty, Ebonyi State & \multicolumn{1}{l}{ University, Abakaliki }
\end{tabular} & Building & $\begin{array}{l}\text { Design-bid } \\
\text { and build } \\
\text { (DBB) }\end{array}$ & $\begin{array}{l}\text { Risk Identification } \\
\text { Risk Quantification } \\
\text { Risk Response } \\
\text { Development } \\
\text { Risk Response Control }\end{array}$ \\
\hline
\end{tabular}


116 | International Journal of Scientific and Management Research 4(5) 106-123

\begin{tabular}{|c|c|c|c|c|}
\hline 10. & $\begin{array}{l}\text { Administrative } \text { Building, } \\
\text { University of Nigeria, } \\
\text { Nsukka }\end{array}$ & $\begin{array}{l}\text { Civil } \\
\text { Engineering }\end{array}$ & Design-build & $\begin{array}{l}\text { Risk Identification } \\
\text { Risk Quantification } \\
\text { Risk Response } \\
\text { Development } \\
\text { Risk Response Control } \\
\end{array}$ \\
\hline 11. & $\begin{array}{l}\text { Faculty Of Social Sciences } \\
\text { In University of Nigeria, } \\
\text { Nsukka. }\end{array}$ & $\begin{array}{l}\text { Civil } \\
\text { Engineering }\end{array}$ & $\begin{array}{l}\text { Design-bid } \\
\text { and build } \\
(\mathrm{DBB})\end{array}$ & $\begin{array}{l}\text { Risk Identification } \\
\text { Risk Quantification } \\
\text { Risk Response } \\
\text { Development } \\
\text { Risk Response Control }\end{array}$ \\
\hline 12. & $\begin{array}{l}\text { Administrative } \text { Building, } \\
\text { College of Education, } \\
\text { Ihamufu. }\end{array}$ & Building & $\begin{array}{l}\text { Design-bid } \\
\text { and build } \\
(\mathrm{DBB})\end{array}$ & $\begin{array}{l}\text { Risk Identification } \\
\text { Risk Quantification } \\
\text { Risk Response } \\
\text { Development } \\
\text { Risk Response Control }\end{array}$ \\
\hline 13. & $\begin{array}{l}\text { Architecture Department in } \\
\text { Federal Polytechnic, } \\
\text { Nekede }\end{array}$ & Building & $\begin{array}{l}\text { Design-bid } \\
\text { and build } \\
(\mathrm{DBB})\end{array}$ & $\begin{array}{l}\text { Risk Identification } \\
\text { Risk Quantification } \\
\text { Risk Response } \\
\text { Development } \\
\text { Risk Response Control } \\
\end{array}$ \\
\hline 14 & $\begin{array}{l}\text { Abia Specialist } \\
\text { and Dospital } \\
\text { Umuahia }\end{array}$ & $\begin{array}{l}\text { Civil } \\
\text { Engineering }\end{array}$ & \begin{tabular}{l}
\multicolumn{2}{l}{ Design-bid } \\
and build \\
$(\mathrm{DBB})$
\end{tabular} & $\begin{array}{l}\text { Risk Identification } \\
\text { Risk Quantification } \\
\text { Risk Response } \\
\text { Development } \\
\text { Risk Response Control }\end{array}$ \\
\hline 15 & $\begin{array}{l}\text { Nnamdi Azikiwe University } \\
\text { Teaching Hospital, Nnewi, } \\
\text { Anambra. }\end{array}$ & Building & \begin{tabular}{l}
\multicolumn{2}{l}{ Design-bid } \\
and build \\
$(\mathrm{DBB})$
\end{tabular} & $\begin{array}{l}\text { Risk Identification } \\
\text { Risk Quantification } \\
\text { Risk Response } \\
\text { Development } \\
\text { Risk Response Control }\end{array}$ \\
\hline 16 & $\begin{array}{l}\text { University of Nigeria } \\
\text { Teaching Hospital, Ituku- } \\
\text { Ozalla Enugu State }\end{array}$ & $\begin{array}{l}\text { Civil } \\
\text { Engineering }\end{array}$ & $\begin{array}{l}\text { Design-bid } \\
\text { and build } \\
(\mathrm{DBB})\end{array}$ & $\begin{array}{l}\text { Risk Identification } \\
\text { Risk Quantification } \\
\text { Risk Response } \\
\text { Development } \\
\text { Risk Response Control }\end{array}$ \\
\hline 17. & $\begin{array}{l}\text { Annunciation Specialist } \\
\text { Hospital Emene, Enugu. }\end{array}$ & Building & \begin{tabular}{l}
\multicolumn{2}{l}{ Design-bid } \\
and build \\
$(\mathrm{DBB})$
\end{tabular} & $\begin{array}{l}\text { Risk Identification } \\
\text { Risk Quantification } \\
\text { Risk Response } \\
\text { Development } \\
\text { Risk Response Control }\end{array}$ \\
\hline
\end{tabular}


117 | International Journal of Scientific and Management Research 4(5) 106-123

\begin{tabular}{|l|l|l|l|l|}
\hline 18. & $\begin{array}{l}\text { New Anambra State } \\
\text { University } \\
\text { Hospital Awka. }\end{array}$ & $\begin{array}{l}\text { Civil } \\
\text { Teaching }\end{array}$ & $\begin{array}{l}\text { Design-bid } \\
\text { End build } \\
\text { (DBB) }\end{array}$ & $\begin{array}{l}\text { Risk Identification } \\
\text { Risk Quantification } \\
\text { Risk } \\
\text { Development } \\
\text { Risk Response Control }\end{array}$ \\
\hline 19. & $\begin{array}{l}\text { National Obstetric Fistula } \\
\text { Centre, Abakaliki. }\end{array}$ & Building & $\begin{array}{l}\text { Design-bid } \\
\text { and build } \\
\text { (DBB) }\end{array}$ & $\begin{array}{l}\text { Risk Identification } \\
\text { Risk Quantification } \\
\text { Risk } \\
\text { Development Response } \\
\text { Risk Response Control }\end{array}$ \\
\hline 20. & $\begin{array}{l}\text { Ezem Medical Centre, } \\
\text { Owerri }\end{array}$ & Building & $\begin{array}{l}\text { Design-bid } \\
\text { and build } \\
\text { (DBB) }\end{array}$ & $\begin{array}{l}\text { Risk Identification } \\
\text { Risk Quantification } \\
\text { Risk } \\
\text { Development Response } \\
\text { Risk Response Control }\end{array}$ \\
\hline
\end{tabular}

Source: Researcher's Field Survey (2018)

Table 1 revealed the results of direct observations and walkthrough evaluations carried out by the researcher. From the table, it was found that the buildings investigated in the study area were Hospitals, Tertiary Institutions and Government Secretariats across the South-East Zone.

Design-build procurement option, with a lump sum payment mechanism, was chosen in the construction of some building projects in the study area. The project implementation was very good in terms of time and fairly good in terms of quality. In terms of budget, the project was very good for the clients and fairly bad for the contractors in some of the projects executed.

Some identified risks occurred in the projects, but their effect on the project cost was fairly small. The unforeseen risks during the project execution led to a fairly large increase in project cost.

A design-bid-build contract was signed between the client and the contractor in the construction of majority of the buildings in the study area. The technical characteristics of the final product were evaluated as very good and the time constraints for project execution were kept. However, the poor quality of the design documents (in some cases) increased the contractor's costs significantly. Thus, in terms of budget, the project was very good for the client and fairly bad for the contractor. Identified risks occurred in the project and had a fairly large effect on the project cost; even so, the consequences of unforeseen risks were fairly small.

Two types of projects were observed in the building construction. They are building projects and civil engineering projects. Also, the risk management practices applied for different procurement options are risk identification risk quantification risk response development and risk response control. 


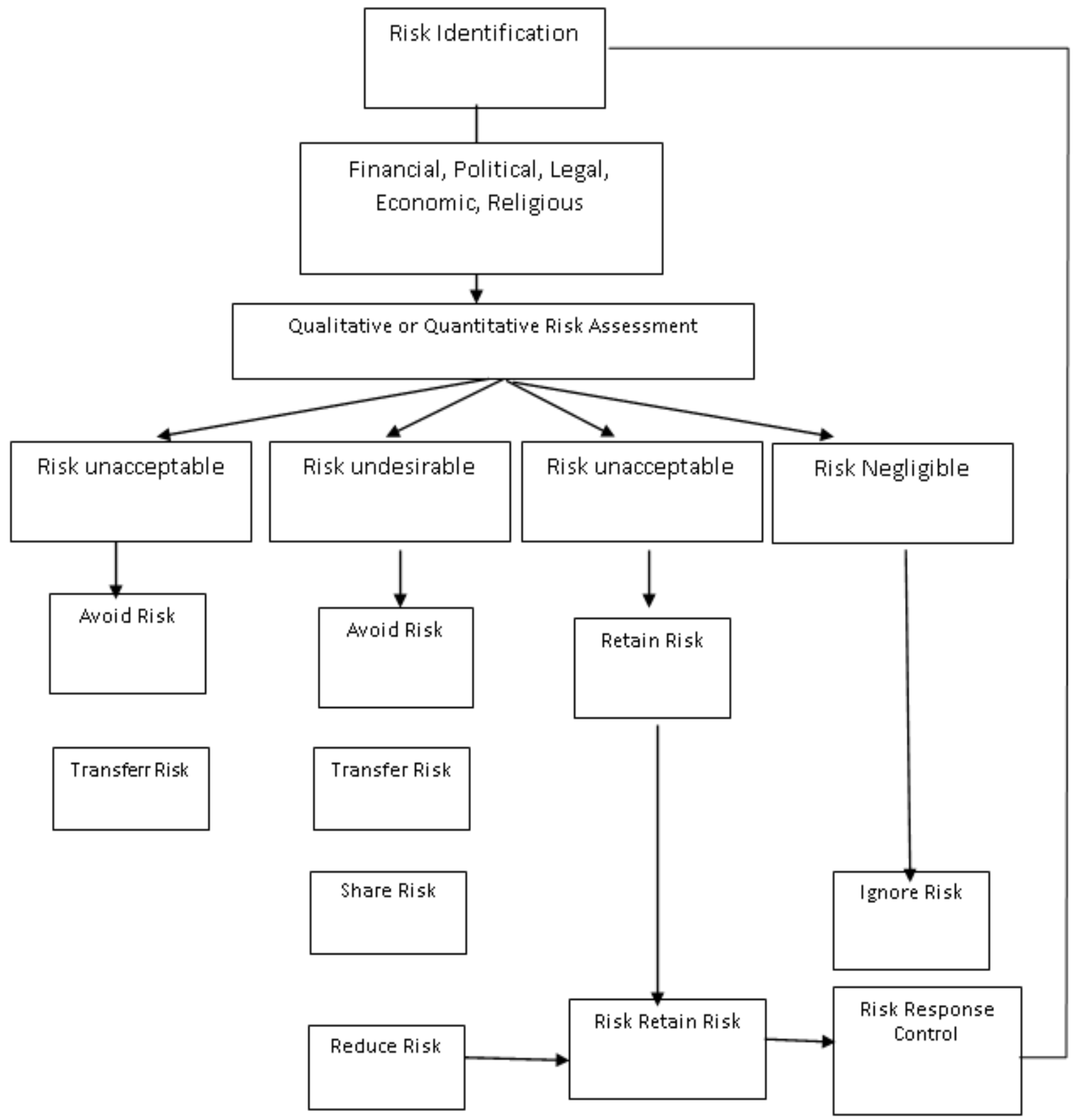

Fig 1: Showing Integrated Risk Management Framework/ Process for Public Building Procurement in South East Nigeria.

\section{Source: Adapted from Ceric, Marcic and Ivandic (2011).}

Risk management is an activity process which defines the sources of uncertainty (risk identification), estimates the consequences of uncertain events/conditions (risk analysis) and generates response strategies (Zavadskas et al, 2010). Figure 1 shows the cyclical risk management process, which is carried out independently for each phase of the construction project. Risk management in construction is a tedious task as the objective functions tend to change during the 


\section{9 | International Journal of Scientific and Management Research 4(5) 106-123}

project life cycle (Dikmen et.al, 2007). Bobick (2010) stated that a properly implemented risk management process will enhance the successful completion of building construction projects and thereby make the projects more profitable. He added that when risk management is applied chaotically and arbitrarily, it can jeopardize the realization of the project as most of the risks are very dynamic all the way throughout the project lifecycle.

Nevertheless, Ceric, Marcic and Ivandic (2011) was of the view that sundry factors like; unforeseeable change in local laws and procedures, weather, type of contract, size of contract, project location, site condition, experience and incentives of field staff, content of the project specifications, contract period, punitive damages, arbitration clause, knowledge of client and consultant average, attitude towards changes and environmental issues can aid in the development of a risk management index (RMI) in building construction companies. Lerad (2014) asserted that there are some pertinent parameters that necessitate the development of a risk management index (RMI) in building construction companies across the globe. These parameters include: currency exchange fluctuation average, economic instability, inflation pressure, punctuality of periodical payments, number of competitors, and level of competition, estimating method, and accuracy of bidding documents provided by client among others.

The financial risks in public procurement are mainly twofold, one related to the uncertainty in meeting target costs, the other to the ability to secure the funds needed in the first place. According to ECEG (2010), there are three major tasks for risk management: Firstly, to define and assess risks and rewards for all partners involved at the various stages of the procurement process, including the nature of risks, which may change during the various procurement stages, the causes and source for risk, the likelihood of risks to occur, and the potential consequences of risk occurrence (additional costs, reduced rewards).

Second, for each risk, to take action to avoid or reduce the likelihood of the risk to materialize and allocate responsibilities to take action to reduce the likelihood. Third, for each risk, to define actions to mitigate the potential consequences and allocate who bears the cost of mitigation and the reduced benefits (see also Ward \& Chapman, 1991; Hood \& Rothstein, 2000; Zhao \& Duan, 2008). Different specific risk-management methods exist to manage risks, including awareness measures, contract design, early supplier involvement, training schemes, etc. (ECEG, 2010).

\section{Conclusion and Recommendation}

Evidence from literature showed that Risk is a complex phenomenon that has physical, monetary, cultural and social dimension. Risk in construction is a variable in the construction process whose variation results in uncertainty as to the final cost, duration and quality of the project. Project risks are uncertain events or conditions that may have an impact on one or several project objectives. Risk assessment is defined as the process of assessing the risks associated with each of the hazards identified so the nature of the risk can be understood. This includes the nature of the harm that may result from the hazard, the severity of that harm and the likelihood of this occurring. A risk assessment is a systematic examination of a task, job or process that one carry out at work for the 
purpose of identifying the significant hazards, the risk of someone being harmed and deciding what further control measures one must take to reduce the risk to an acceptable level. Management is the organizational process that includes strategic planning, setting objectives, managing resources, deploying the human and financial assets needed to achieve objectives, and measuring results. Risk management is an activity which integrates recognition of risk, risk assessment, developing strategies to manage it, and mitigation of risk using managerial resources. Some traditional risk managements are focused on risks stemming from physical or legal causes (e.g. natural disasters or fires, accidents, death). Risk management in the construction project management context is a systematic way of identifying, analyzing and dealing with risk as associated with a project with an aim to achieve the project objectives. Project risk management is an integrated process which includes activities to identify project uncertainty, estimate their impact, analyze their interactions, control them in the execution stage, and even provide feedback to the maintenance of collective knowledge asset.

The study recommends the above risk management index for effective risk management process for public building procurement options in Nigeria. Risk management is a process which cut across identification of risk, classification of identified risk (financial, political, legal, economic and religious factors), carrying out a qualitative and quantitative assessment of the classified risk, estimates the consequences of uncertain events/conditions (risk analysis) and generates response strategies. According to Bobick (2010) a properly implemented risk management process will enhance the successful completion of building construction projects and thereby make the projects more profitable. He added that when risk management is applied chaotically and arbitrarily, it can jeopardize the realization of the project as most of the risks are very dynamic all the way throughout the project lifecycle.

Conclusively, in order to improve the chance of success and reduce these potential risks associated with building construction projects in Nigeria, risk management that is guided with the above framework should be an important part of the decision-making process for a construction enterprise.

\section{References}

1) Anaman, E. and Osei-Amponsah An, R. (2007). Evaluation of the Delivery Performance of Construction Projects Funded by the District Assemblies' Common Fund" (A case Study of 4 Districts in Ashanti Region), Unpublished M Sc. Thesis submitted to the Department of Building Technology, KNUST, 2007

2) Ashworth, A. and Hogg, K. (2007). Willis's practice and procedure for quantity surveyor. Oxford, UK: Blackwell Publishing Ltd.

3) Babatunde, S. O., Opawole, A. \& Ujaddugbe, I. C., (2010).Appraisal of project procurement methods in Nigeria. Civil Engineering Dimension, 12(1),1-7. 
121 | International Journal of Scientific and Management Research 4(5) 106-123

4) Bing L, Tiong L.R, Fan W.W and Chew D.A, (2009). Risk management in international construction joint ventures; Journal of construction engineering and management, 125 , 277-284.

5) Bobick, T.G. (2010). Deaths and injuries caused by falls through roof and floor openings and surfaces, including skylights. National Occupational Injury Research Symposium, Pittsburgh, PA, USA; pp. 14.

6) Bru, G. (2013). Control of deformation of buildings affected by subsidence using persistent scatterer interferometry. Structure and Infrastructure Engineering. 9(2), 188-200.

7) Ceric A, Marcic D and Ivandic K, (2011). A risk assessment methodology in tunneling.Technical news/technical Gazette, 18(4), 529-536.

8) Chan E.H.W. and Lee, G.K.L. (2008).A sustainability evaluation of government-led urban renewal projects, Journal of Facilities, 26(13), 526-541.

9) Chapman, R. J, (2011). The controlling influences on effective risk identification and assessment for construction design management; International Journal of Project Management, 19(3), 147-160.

10) Dada, M.O. (2012). A second look: Stakeholders' perceptions of some issues in design bid-build procurement practice in Nigeria. Journal of Sustainable Development, 5(T), 5563.

11) Federal Office of Statistics (FOS) (2004). Quarterly Report: Federal ministry of works and housing, Abuja, Nigeria. Abuja: FGN Press.

12) Hardie, F. (2007). Strategic sourcing in the new economy: Harnessing the potential of sourcing business models for modern procurement. New York: Palgrave Macmillan.

13) Ibiyemi, A.O., Adenuga, A.O. \& Odusami, K.T. (2008). Comparative analysis of design and build and the traditional procurement methods in Lagos, Nigeria. Journal of Construction 2(2), 2-6.

14) Idrus, A. B. and Sodangi, M. (2008). Framework for evaluating quality performance of contractors in Nigeria. International Journal of Civil \& Environmental Engineering IJCEE-IJENS, 10, 34 - 39.

15) Kadiri, D. S. \& Odusami, K. T. (2003). Comparative study of time and cost performance of direct labour and labour only procurement system, Journal of the Nigerian Institute of Quantity Surveyors, 44(3), 88-98.

16) Kangari, R. (1995). Risk management perception and trend of US construction. Journal of construction Engineering and management, 121(4), 422-429.

17) Lerad, A. (2014). Top management planning. New York: Macmillan.

18) Maizon, H, (2006), Factors Influencing the selection procurement systems by clients, Proceedings of International Conference on Construction Industry, Padang, Indonesia.

19) Mansfield, N. R. Ugwu. O. O and Doran, T. (2004). Causes of delay and cost overruns in Nigerian construction projects. International Journal of Project Management, 12, 254- 260. 
20) Masterman, J. (2002). Introduction to building procurement systems. 2nd ed. London: Spon Press.

21) Max J. E. \& David M.M. (2002). Geographic information science: second international conference, GI Science 2002, Boulder, CO, USA, September 25-28, 2002: proceedings", Springer, p. 110. Books.google.fr. 2002-09-13. Retrieved 2014-08-22.

22) Moban, H. (2014), Real estate investment analysis and taxation. Atlanta: McGraw-Hill, p. 210

23) Muriro, A. and Wood, G. (2010), A comparative analysis of procurement methods used on competitively tendered office projects in the UK, Proceedings of The Construction Building and Real Estate Research Conference of the Royal Institution of Chartered Surveyors (COBRA), Dauphine University, Paris.

24) Odeyinka, H.A. and Yusuf, A. (2007). The causes and effects of construction delays on cost of housing project in Nigeria, Journal of Financial Management and Property and Construction, 2, 31-41.

25) Ogunsanmi, O.E. Iyagba, R.O.A. \& Omirin, M. M. (2003). Modelling procurement performance in housing projects in Nigeria, The Lagos Journal of Environmental Sciences, 3(1), 16- 35.

26) Ogunsemi, D. R. \& Jagboro, G. O. (2006). "Time-cost model for building projects in Nigeria. Journal of Construction Management and Economics, 2, 253-258.

27) Ojo, S.O; Adeyemi, A.Y and Fagbenle O.I. (2006). The Performance of traditional contract procurement on housing projects in Nigeria: Civil engineering dimension. Journal of Civil Engineering Science and Application, 8, (2), 81-86.

28) Onyema, M. (2001). Challenges and prospects of public procurement practice in Nigeria By Mazi Emmanuel Onyema. [Online] Available at: http://newsdiaryonline.com/procured.htm [Accessed: 26 May 2013]

29) Paul F.W. and Alan R. C. (2009), Real estate investment analysis and taxation. Atlanta: McGraw-Hill.

30) PMI (2008). Guide to the project management body of knowledge (PMBOK Guide), 4th ed. Newtown Square: Project Management Institute.

31) Ramus. J., (2006), Contract practice for Surveyors, 4th Edition, Laxton, Great Britain

32) Rashid, R. A., (2006), Effects of procurement systems on the performance of construction projects, proceedings of International Conference on Construction Industry, Padang, Indonesia.

33) Richards, P. (2005), Client strategies objectives: The impact of choice of construction contract on project Delivery, Construction Law Journal, 7 (21), 56-68.

34) Smith, N. J, Merna, T and Jobling, P. (1999).Managing risk in construction projects. Oxford: Blackwell Science Press.

35) Sturgis, Russell (2011). A dictionary of architecture and building: biographical, historical, and descriptive. vol. 1. New York: The Macmillan Co. 
123 | International Journal of Scientific and Management Research 4(5) 106-123

36) Turner, A. (1990). Building procurement. London, UK: Macmillan.UK Construction Industry, Universal J. Mana, 4(4) 203-210.

37) Williams, T. (2005) A classified bibliography of recent research relating to project risk management. European Journal of Operational Research, 85(6), 18-38.

38) Zavadskas, E.Z, Turskis $Z$ \& Tamosaitiene, J, (2010). Risk assessment of construction projects. Journal of Civil Engineering and Management, 6(1), 33-46.

39) Zou, P.X.W., Zhang G and Wang, J. (2007). Understanding the key risk in construction projects in China: International Journal of Project Management, 25, 601-614.

\section{Works Cited}

Ekwelem O., Okolie K.C. and Okongwu M.I. (2021). Conceptual Framework of Risk Management for Public Building Procurement Systems in South- East, Nigeria. International Journal of Scientific and Management Research, 04(05), 106-123. doi: http://doi.org/10.37502/IJSMR.2021.4506 